\title{
MODIFICATION OF THE SINGLE SULFHYDRYL GROUP OF CARBOXYPEPTIDASE Y WITH MERCURIALS. INFLUENCE ON ENZYME SPECIFICITY
}

\author{
by \\ KLAUS BREDDAM \\ Department of Chemistry, Carlsberg Laboratory \\ Gamle Carlsberg Vej 10, DK-2500 Copenhagen Valby
}

Keywords: Carboxypeptidase Y, kinetics, mercuric chloride, phenylmercuric chloride, anions

\begin{abstract}
Modification of the single sulfhydryl group of carboxypeptidase $\mathrm{Y}$ with one equivalent $\mathrm{Hg}$ resulted in an inactive enzyme when assayed in the absence of halides regardless of the nature of the amino acid residue in the $P_{1}$ position of the ester substrate. Anions capable of complexing with $\mathrm{Hg}^{+}$, i.e., $\mathrm{Cl}^{-}, \mathrm{Br}, \mathrm{I}^{-}, \mathrm{SCN}^{-}$and $\mathrm{CN}^{-}$, partially reactivated the $\mathrm{Hg}$ modified $\mathrm{CPD}-\mathrm{Y}$ to a level of $20-28 \%$ of the esterase activity of the unmodified enzyme. The concentration of anion necessary to achieve maximal activation varied and the following dissociation constants were determined: $\mathrm{Cl}: \mathrm{pK}_{d}=1.8, \mathrm{SCN}-: \mathrm{pK}_{d}=3.4, \mathrm{Br}^{-} \mathrm{pK}_{d}=3.6, \mathrm{I}: \mathrm{pK}_{d}=5.4, \mathrm{CN}-: \mathrm{pK}_{\mathrm{d}}>7$. The relation between activation and concentration of anion was in agreement with binding of one equivalent of anion to the enzyme bound mercury. A similar reactivation was not observed for CPD-Y partially inactivated with phenylmercuric chloride.

The kinetic constants for a series of ester substrates with the general formula Bz-X-OMe, where $\mathrm{X}=$ amino acid residue, were determined for unmodified CPD-Y, CPD-Y modified with $\mathrm{Hg}^{+}$(assayed in the presence of $\mathrm{I}^{-}$) and CPD-Y reacted with phenylmercuric chloride. Unmodified CPD.Y exhibited a strong preference for substrates with hydrophobic amino acid residues, i.e., Phe, Leu, Met, and only slowly hydrolyzed substrates with hydrophilic amino acid residues, i.e., Arg, Lys, $T h r$, Gly. The two modified enzymes also had the highest $k_{\text {cat }} / K_{m}$ for substrates with hydrophobic residues. However, their relative preference for these different substrates deviated substantially from the unmodified enzyme. The increased preference for $\mathrm{Bz}-\mathrm{Lys}-\mathrm{OMe}$ when the $\mathrm{Hg}^{++}$modified enzyme was used and for Bz-Gly-OMe and Bz-Ala-OMe when the phenylmercuric chloride modified enzyme was used were the most pronounced changes in the specificity of CPD-Y following its modification with mercurials.
\end{abstract}

Abbreviations: $\mathrm{Bz}=$ benzoyl; $\mathrm{Bzl}=$ benzyl; Caps $=$ cyclohexylaminopropane sulfonic acid; $\mathrm{CPD}-\mathrm{Y}=$ carboxypeptidase $\mathrm{Y} ; \mathrm{DMF}=\mathrm{N}, \mathrm{N}^{\prime}$-dimethylformamide; Hepes = N-2-hydroxyethylpiperazine-N'-2-ethanesulfonic acid; $+\mathrm{Hg}-\mathrm{CPD}-\mathrm{Y}=$ mercuric chloride inactivated CPD-Y; A-Hg-CPD-Y $={ }^{+} \mathrm{Hg}-\mathrm{CPD}-\mathrm{Y}$ in the presence of anion; I-Hg-CPD- $Y=+\mathrm{Hg}-\mathrm{CPD}-\mathrm{Y}$ in the presence of iodide; $\mathrm{Br}-\mathrm{Hg}-\mathrm{CPD}-\mathrm{Y}=+\mathrm{Hg}-\mathrm{CPD}-\mathrm{Y}$ in the presence of bromide etc.; $\mathrm{Mes}=2(\mathrm{~N}-$ morpholino) ethane sulfonic acid; $\mathrm{Ph}-\mathrm{Hg}-\mathrm{CPD}-\mathrm{Y}=\mathrm{CPD}-\mathrm{Y}$ modified with $\mathrm{Ph}-\mathrm{Hg}-\mathrm{Cl} ; \mathrm{Ph}-\mathrm{Hg}-\mathrm{Cl}=$ phenylmercuric chloride; $Z$ = carbobenzoxy. Abbreviations of amino acids, amino acid derivatives are according to the guideline of the IUPAC-IUB Commission on Biochemical Nomenclature. 


\section{INTRODUCTION}

BAI and HAYASH have recently demonstrated that the inhibition of CPD-Y by mercuric chloride and alkyl mercurials is due to modification of a sulfhydryl group which is not required for the hydrolytic function, since activity is retained towards several substrates (1). They also found that the inhibition with mercurials is most pronounced when the enzyme is assayed against substrates with bulky side chains in the $P_{I}$ position (SCHECHTER-BERGER nomenclature (8)), indicating that the sulfhydryl group is located in the $S_{1}$ binding site of the enzyme. However, while BAI and HAYASHI (1) demonstrated that the activity of CPD-Y towards Bz-Gly- $\beta, \mathrm{L}-$ phenyllactate was decreased to $30 \%$ by addition of 1 equivalent of mercuric chloride, observations in the present laboratory showed that the activity was totally abolished by mercuric chloride. The present paper attempts to explain this discrepancy and demonstrates how the presence of a non-essential sulfhydryl group in a binding site of the enzyme can be utilized for production of chemically modified derivatives with altered enzymatic specificity.

\section{MATERIALS AND METHODS}

\subsection{Materials}

CPD-Y, N-benzoyl-glycine methyl ester, $\mathrm{N}$ benzoyl-L-alanine benzyl ester and N-benzoyl-Lphenylalanine methyl ester were all prepared as previously described $(3,6)$. N-benzoyl-L-lysyl-Lalanine was prepared by enzymatic synthesis (to be published). N-benzoyl-L-alanine methyl ester, $\mathrm{N}$-benzoyl-L-iysine methyl ester, N-benzoyl-Lthreonine methyl ester, $\mathrm{N}$-carbobenzoxy-L-phenylalanyl-L-alanine and $\mathrm{N}$-benzoyl-L-arginine were purchased from Bachem, Switzerland. N. benzoyl-L-valine methyl ester, $\mathrm{N}$-benzoyl-L-isoleucine, N-benzoyl-L-leucine methyl ester, $\mathrm{N}$ benzoyl-L-methionine methyl ester and N-benzoyl-L-histidine methyl ester were products of Vega Biochemicals, USA. N-benzoyl-L-isoleucine methyl ester and N-benzoyl-L-arginine methyl ester were prepared from the corresponding $\mathrm{N}$-blocked amino acids by esterification with methanol/HCl. Hepes, Mes, 2-amino-2-methyl1,2-propanediol and Caps were products of Sigma, USA. All other reagents and solvents were of analytical purity and obtained from Merck, W. Germany.

The mercurial derivatives of CPD- $Y$ were prepared as follows: To $1 \mathrm{ml} \mathrm{CPD}-Y\left(7.6 \mathrm{mg} \cdot \mathrm{ml}^{-1}\right.$ in water) was added $0.1 \mathrm{ml} 0.5 \mathrm{M}$-Hepes, $\mathrm{pH} 7.5$ and $20 \mu 10 \mathrm{~mm}-\mathrm{HgCl}_{2}$ (in water) or $20 \mu \mathrm{l} \mathrm{Ph}-\mathrm{Hg}-\mathrm{Cl}$ (in DMF) to yield +Hg-CPD-Y and Ph-Hg-CPD-Y, respectively. The molar ratio of reagent to enzyme was 1.6 . The mixtures were left for $15 \mathrm{~min}$ at room temperature and then kept on ice $\left(0^{\circ} \mathrm{C}\right)$ for up to 8 hours without further loss of activity.

\subsection{Methods}

Esterase activity towards Bz-Ala-OBzl was routinely determined using the following conditions: $0.5 \mathrm{~mm}$-Bz-Ala-OBzl, $0.05 \mathrm{M}-\mathrm{Hepes}, 2.5 \%$ (v/v) $\mathrm{CH}_{3} \mathrm{OH}, \mathrm{pH}$ 7.5. The hydrolysis was followed spectrophotometrically at $254 \mathrm{~nm}$ using a Cary 219 spectrophotometer. The effect of anions on the activity of $\mathrm{Ph}-\mathrm{Hg}-\mathrm{CPD}-\mathrm{Y}$ and $+\mathrm{Hg}-\mathrm{CPD}-\mathrm{Y}$ was measured with the desired anion included in the assay mixture. Parallel assays of unmodified CPD-Y in the presence of the anions insured that these had no adverse effect on the enzyme. The dissociation constant $\left(\mathrm{K}_{\mathrm{d}}\right)$ of the anion-enzyme complex was determined according to the following equation (based on the assumption that the anion binds to the enzyme in a ratio of $1: 1$ ):

$$
\mathrm{K}_{\mathrm{d}}=\frac{\left[\mathrm{A}^{-}\right][+\mathrm{Hg}-\mathrm{CPD}-\mathrm{Y}]}{[\mathrm{A}-\mathrm{Hg}-\mathrm{CPD}-\mathrm{Y}]}=\frac{\left[\mathrm{A}^{-}\right]\left(\mathrm{V}_{\max }-\mathrm{v}\right)}{\mathrm{v}}
$$

here [A-], [A-Hg-CPD-Y] and [+Hg-CPD-Y] are the concentrations of free anion, anion bound enzyme and free enzyme, respectively; $V_{\max }$ and $v$ represent rates at saturating and given concentrations of anion, respectively. $\left[\mathrm{A}^{-}\right]$was assumed to be equal to the concentration of anion; this only holds if $K_{d}$ is much larger than the total concentration of enzyme. The equation was used in the logarithmic form:

$$
\log \left[A^{-}\right]-\log K_{d}=\log \frac{v}{V_{\max }-v}
$$

The plot of $\log \left(\mathrm{v} /\left(\mathrm{V}_{\max }-\mathrm{v}\right)\right)$ against $\log \left[\mathrm{A}^{-}\right]$ should yield a straight line with a slope of 1 provided that only one equivalent of anion binds to the enzyme. 
Kinetic constants for unmodified CPD-Y and the mercury derivatives of CPD-Y were graphically determined from LINEWEAVER-BURK plots. Activity measurements were performed at $25^{\circ} \mathrm{C}$ with substrate concentrations varying from the highest obtainable concentration down to less than one third of the $K_{m}$ values.

The influence of $\mathrm{pH}$ on the kinetic parameters was studied for the hydrolysis of Bz-Ala-OBzl using the following buffer systems: $\mathrm{pH} 4.0$ - 4.5, 50 mM-acetic acid; $\mathrm{pH} 5.0$ - 6.5, 50 mM-Mes; $\mathrm{pH}$ 7.0 - 8.0, 50 mм-Hepes; $\mathrm{pH} 8.5$ - 9.0, $50 \mathrm{mm-2-}$ amino-2-methyl-1,2-propanediol; pH 9.5, 50 mм-Caps. The $\mathrm{pH}$ of all buffers were adjusted with $\mathrm{NaOH}$ or $\mathrm{HNO}_{3}$. The stability of CPD-Y and its derivatives was investigated by incubating the enzymes in a concentration of $0.05-0.2$ $\mathrm{mg} \cdot \mathrm{ml}^{-1}$ in the same buffer as described above. The activity was followed as a function of time and the assay was performed in the same buffer as the incubation.

\section{RESULTS}

The inhibition of CPD-Y by addition of $\mathrm{HgCl}_{2}$ and $\mathrm{Ph}-\mathrm{Hg}-\mathrm{Cl}$, respectively, was investigated by measuring the esterase activity of the enzyme towards Bz-Ala-OBzl in Hepes buffer. As previously observed $(1,6)$, the enzymatic activity decreased linearly with increasing concentrations of the mercurials until maximal inactivation was reached at approximately equimolar concentration (Figure 1). $\mathrm{HgCl}_{2}$ abolished the esterase activity completely while the enzyme modified with $\mathrm{Ph}-\mathrm{Hg}-\mathrm{Cl}$ had approximately $30 \%$ residual esterase activity. However, further experiments showed that the enzyme modified with $\mathrm{HgCl}_{2}$ sometimes exhibited a residual activity and that this activity depended on the media in which the assays were performed. When the activity of the enzyme towards $\mathrm{Bz}-\mathrm{Ala}-\mathrm{OBzl}$ was measured in Tris- $\mathrm{HCl}$ buffer a residual activity of approximately $20 \%$ was recorded. It could be demonstrated that this reactivation of $+\mathrm{Hg}-\mathrm{CPD}-\mathrm{Y}$ was due to chloride ions present in the Tris buffer since the enzyme was devoid of activity when assayed in Tris- $\mathrm{HNO}_{3}$ buffer. Other anions, such as $\mathrm{Br}, \mathrm{I}^{-}, \mathrm{SCN}^{-}$and $\mathrm{CN}^{-}$, known to form complexes with $\mathrm{Hg}^{+}$, had a similar capacity to reactivate ${ }^{+} \mathrm{Hg}-\mathrm{CPD}-\mathrm{Y}$.

The reactivation of $+\mathrm{Hg}-\mathrm{CPD}-\mathrm{Y}$ as a function

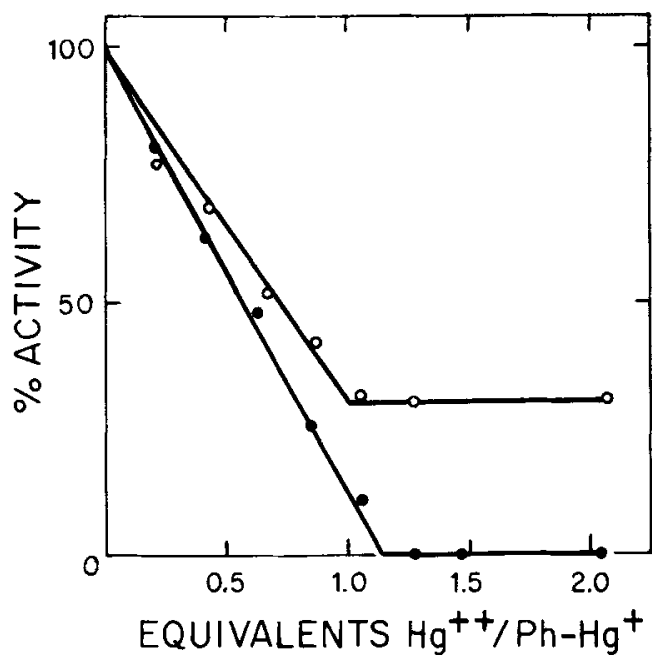

Figure 1: Inactivation of CPD-Y with $\mathrm{HgCl}_{2}(\bullet)$ and Ph-Hg-CPD-Y (O).

The enzyme was incubated at a concentration of 3.8 $\mathrm{mg} \mathrm{ml}^{-1}$ in $0.05 \mathrm{M}$-Hepes, $\mathrm{pH} 7.5$, with increasing amounts of mercurial for 15 minutes. Subsequently, the enzyme was assayed at $25^{\circ} \mathrm{C}$ towards Bz-Ala-OBzl as described in section 2.2 .

of added KI is shown in Figure 2. It is seen that a maximal reactivation corresponding to $22 \%$ of the activity of unmodified CPD-Y was obtained. The activity of the enzyme modified with $\mathrm{Ph}-\mathrm{Hg}-\mathrm{Cl}$ (Ph-Hg-CPD-Y) was not influenced by addition of $\mathrm{KI}$ to the assay mixture (Figure 2). To

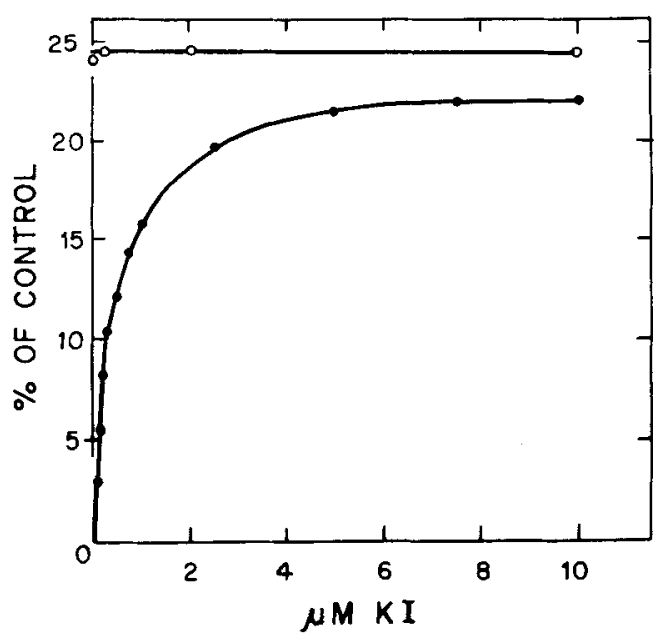

Figure 2: Effect of $\mathrm{KI}$ on the esterase activity of $+\mathrm{Hg}$-CPD-Y (- - - -) and Ph-Hg-CPD-Y (- $\mathrm{O}-\mathrm{O}-\mathrm{O}-\mathrm{-})$. The enzyme was assayed as described in Figure 1. 
confirm that $\mathrm{I}^{-}$and other halide ions exerted their activation effect by complexing with $+\mathrm{Hg}-\mathrm{CPD}-\mathrm{Y}$ and not by chelating the metal and thus removing it from the protein, the following experiment was performed: $+\mathrm{Hg}-\mathrm{CPD}-\mathrm{Y}(30 \mu \mathrm{M})$ was incubated with $\mathrm{KI}(1 \mathrm{~mm})$ in $0.05 \mathrm{M}$-Hepes, pH 7.5 , for $30 \mathrm{~min}$, the reaction mixture was gelfiltered on a Sephadex G-25 (fine) column, equilibrated and eluted with $0.05 \mathrm{~m}-\mathrm{Hepes,} \mathrm{pH}$ 7.5 , to remove the salt and other low molecular weight substances. The recovered protein was then found to be inactive when the assay with Bz-Ala-OBzl was performed in the absence of $\mathrm{KI}$. Addition of $\mathrm{KI}(0.1 \mathrm{~mm})$ resulted in restoration of approximately $20-25 \%$ of the activity of the native enzyme while removal of mercury with mercaptoethanol $(1 \mathrm{mM})$ restored the ac tivity to the level expected of unmodified CPD-Y. These observations provide evidence that the activation effect of I- ions is not a consequence of the removal of the metal ion from $+\mathrm{Hg}-\mathrm{CPD}-\mathrm{Y}$.

The dissociation constant $\left(\mathrm{K}_{\mathrm{d}}\right)$ was determined by assay of the activity of $+\mathrm{Hg}-\mathrm{CPD}-\mathrm{Y}$ towards $\mathrm{Bz}-\mathrm{Ala}-\mathrm{OBzl}$ in the presence of various concentrations of anions. $+\mathrm{Hg}-\mathrm{CPD}-\mathrm{Y}$ could be added directly to the assay mixture without prior incubation of anion and enzyme since the anion was bound to the enzyme within the mixing time. The different anions varied in their ability to activate $+\mathrm{Hg}-\mathrm{CPD}-\mathrm{Y}, \mathrm{CN}$ - being the anion required in the lowest concentration and $\mathrm{Cl}^{-}$in the highest concentration to obtain maximal reactivation of theenzyme. Theplotsof $\log \left(\mathrm{v} /\left(\mathrm{V}_{\max }-\mathrm{v}\right)\right)$ against $\log \left[\mathrm{A}^{-}\right]$yielded straight lines with slopes

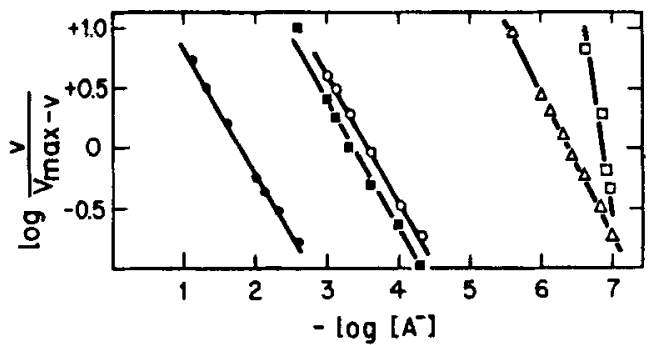

Figure 3: Influence of different anions on the esterase activity of $+\mathrm{Hg}$-CPD-Y.

An enzyme concentration of $4 \cdot 10^{-8} \mathrm{M}$ was utilized. $\mathrm{A}^{-}=$anion, was added to the assay mixture in the form of $\mathrm{KCl}(\bullet), \mathrm{KBr}(O), \mathrm{KI}(\Delta), \mathrm{KCN}(\square)$ or $\mathrm{KSCN}$ (घ). The enzyme was assayed as described in Figure 1.
Table I.

Anion activation of $+\mathrm{Hg}$-CPD-Y.

\begin{tabular}{|c|c|c|c|}
\hline \multirow{2}{*}{$\begin{array}{l}\text { Anion } \\
\text { added }\end{array}$} & $\mathrm{v}_{\mathrm{A}-\mathrm{Hg}-\mathrm{CPD}-\mathrm{Y}}$ & \multirow[b]{2}{*}{$\begin{array}{c}\text { A-Hg-CPD-Y } \\
-\log \left(K_{d}\right) \\
\end{array}$} & \multirow[b]{2}{*}{$\begin{array}{l}\text { A- } \mathrm{Hg}^{+} \\
-\log \left(K_{d}\right)\end{array}$} \\
\hline & $\begin{array}{c}{ }^{{ }^{C} \mathrm{CPD}-\mathrm{Y}} \\
\% \\
\end{array}$ & & \\
\hline $\mathrm{Cl}^{-}$ & 24 & 1.8 & 6.7 \\
\hline SCN- & 20 & 3.4 & \\
\hline $\mathrm{Br}-$ & 25 & 3.6 & 9.1 \\
\hline $\mathrm{I}^{-}$ & 22 & 5.4 & 12.9 \\
\hline $\mathrm{CN}-$ & 28 & $>7$ & \\
\hline
\end{tabular}

$\mathrm{v}_{\mathrm{A}-\mathrm{Hg}-\mathrm{CPD}-\mathrm{Y}}$ represents the esterase activity of $\mathrm{A}-\mathrm{Hg}-\mathrm{CPD}-\mathrm{Y}$ towards $\mathrm{Bz}-\mathrm{Ala}-\mathrm{OBzl}$ at saturating concentration of anion. $\mathrm{v}_{\mathrm{CPD}-\mathrm{Y}}$ represents the corresponding activity of unmodified CPD-Y. The values for $-\log \left(\mathrm{K}_{\mathrm{d}}\right)$ are derived from the curves in Figure 3 in the case of $\mathrm{A}-\mathrm{Hg}-\mathrm{CPD}-\mathrm{Y}$, whereas for $\mathrm{A}-\mathrm{Hg}+$ they are taken from ref. 10.

of approximately 1 for $\mathrm{Cl}^{-}, \mathrm{Br}^{-}, \mathrm{I}^{-}$and $\mathrm{SCN}^{-}$as demonstrated in Figure 3, in agreement with +Hg-CPD-Y binding only one equivalent of anion. With $\mathrm{CN}-$ a plot with a slope higher than 1 is obtained, probably because in this experiment $\mathrm{K}_{\mathrm{d}}$ is similar to the concentration of the enzyme $\left(4 \cdot 10^{-}{ }_{M}\right)$. In Table $I$ is listed the activity of A-Hg-CPD-Y at the different saturating concentrations of anions as percentage of the activity of unmodified CPD-Y. Only a slight dependence of the anion is registered. The values of $\mathrm{pK}_{\mathrm{d}}$, determined from Figure 3, are also listed in Table I and compared with $\mathrm{pK}_{\mathrm{d}}$ for the equilibrium between free $\mathrm{Hg}^{+}$and anion: $\mathrm{Hg}++\mathrm{A}-\rightleftharpoons \mathrm{HgA}^{+}$. It is apparent that the anion$\mathrm{Hg}-\mathrm{CPD}-\mathrm{Y}$ complex is less stable than the anion$\mathrm{Hg}^{+}$complex.

The stability of the mercuric chloride and phenylmercuric chloride derivatives of CPD-Y was investigated by incubation in various buffers at $25^{\circ} \mathrm{C}$. It is apparent from Figure 4 that while all three enzymes are stable for 4 hours at $\mathrm{pH} 5.0$ only the unmodified enzyme remain stable at $\mathrm{pH}$ 7.5. The difference in stability becomes more pronounced at $\mathrm{pH} 9.0$ and $\mathrm{pH} 10.0$.

The determination of kinetic parameters was based on Lineweaver-Burk plots which in no cases showed deviations from linearity. The $k_{\text {cat }}$ values for the hydrolysis of Bz-Ala-OBzl by CPD-Y are apparently dependent on the deprotonation of an ionizable group with a $\mathrm{pK}_{\mathrm{a}}$ of 
approximately 5.2 (Figure $5 \mathrm{~A}$ ) while $\mathrm{K}_{\mathrm{m}}$ is dependent on the deprotonation of an ionizable group with a $\mathrm{pK}_{\mathrm{a}}$ below 5 . With I-Hg-CPD-Y $\mathrm{k}_{\text {cat }}$ is similarly dependent on the deprotonation of an ionizable group with a $\mathrm{pK}_{\mathrm{a}}$ of approximately 5.5 (Figure 5B) while $K_{m}$ is dependent on the deprotonation of an ionizable group with a $\mathrm{pK}_{\mathrm{a}}$ below 5.5. In this case there is in addition a decrease in $k_{\text {cat }}$ between $\mathrm{pH} 8.0$ and 9.5. With $\mathrm{Ph}-\mathrm{Hg}-\mathrm{CPD}-\mathrm{Y} \mathrm{k}_{\text {cat }}$ again depends on the deprotonation of an ionizable group with a $\mathrm{pK}_{\mathrm{a}}$ of approximately 5.2 while $\mathrm{K}_{\mathrm{m}}$ depends on a group with a $\mathrm{pK}_{\mathrm{a}}$ of 6.5 , which is significantly different from the value observed with the unmodified enzyme. For all the enzymes investigated $k_{\text {cat }}$ is maximal and $\mathrm{K}_{\mathrm{m}}$ is minimal in the $\mathrm{pH}$ range 7.5 to 8.0 and consequently the further characterization was carried out at $\mathrm{pH} 7.5$.

Hydrolysis of Bz-Ala-OMe by all three en-

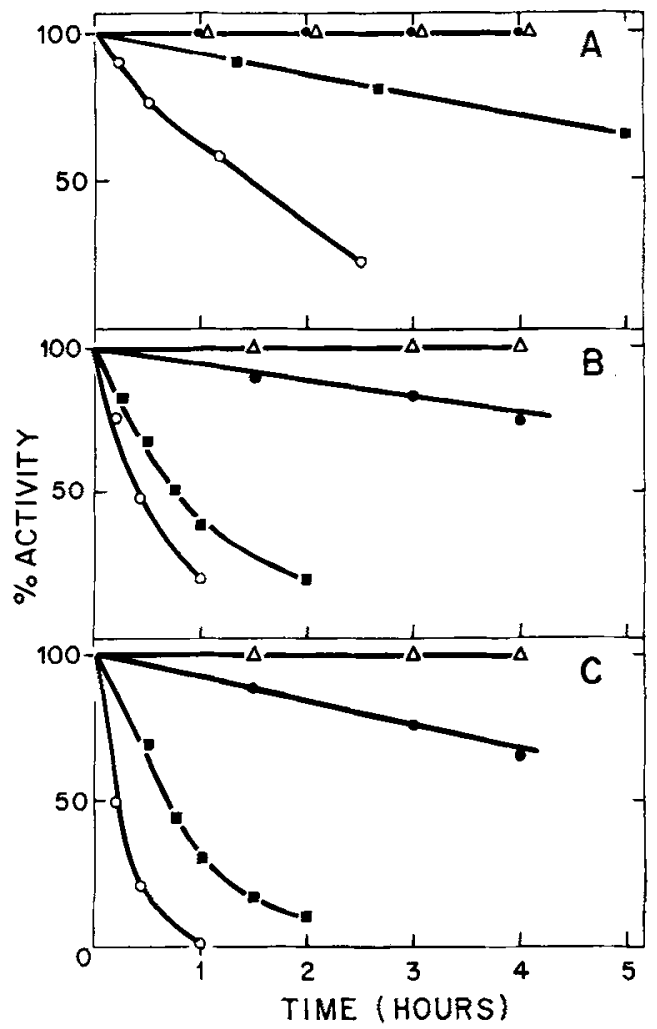

Figure 4: Stability of CPD-Y (Panel A), I-Hg-CPD-Y (Panel B) and Ph-Hg-CPD-Y (Panel C) at pH 5.0, - $\Delta$ $\Delta-;$ pH 7.5, - - - -; pH 9.0, - - - -; pH 10.0, - O- O-. The enzyme was assayed as described in Figure 1.

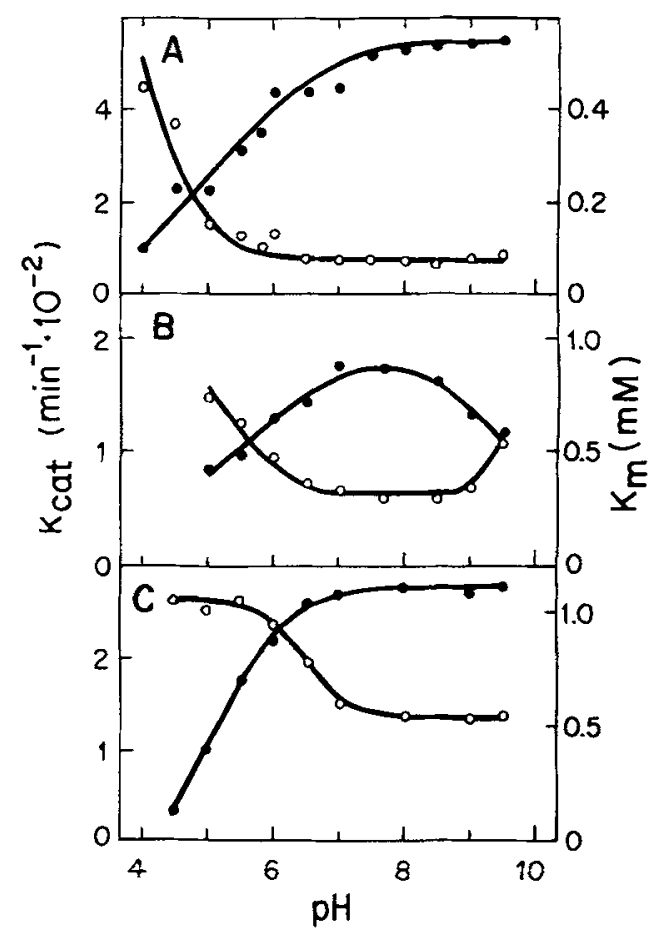

Figure 5: $\mathrm{pH}$ dependence of $\mathrm{k}_{\mathrm{cat}}(-\bullet-\bullet)$ and $\mathrm{K}_{\mathrm{m}}(-\mathrm{O}-$ O-) for the CPD-Y (Panel A), I-Hg-CPD-Y (Panel B) and $\mathrm{Ph}-\mathrm{Hg}$-CPD-Y (Panel C) catalyzed hydrolysis of Bz-Ala-OBzl. The buffers used are described in section 2.2 .

zymes was characterized by much higher $K_{m}$ and somewhat lower $k_{\text {cat }}$ values than those determined with Bz-Ala-OBzl suggesting the size of the leaving group of the substrate to influence the kinetic parameters of the reaction (Table II). Relative to unmodified CPD-Y, the I-Hg-CPD-Y and $\mathrm{Ph}-\mathrm{Hg}-\mathrm{CPD}-\mathrm{Y}$ catalyzed hydrolysis of Bz-Ala-OBzl and Bz-Ala-OMe is characterized by higher $K_{m}$ values and lower $k_{\text {car }}$ values for both substrates.

The specificity of CPD-Y, I-Hg-CPD-Y and Ph-Hg-CPD-Y was compared using a series of ester substrates of the type Bz-X-OMe with various amino acid residues in the $\mathrm{X}$-position, which binds to the $S_{1}$ binding site of the enzyme (Table III). For CPD-Y a complex pattern is observed but the general trend is that the hydrolysis of substrates with hydrophobic amino acid residues in the $P_{1}$ position is characterized by high $k_{\text {cat }}$ values and low $K_{m}$ values whereas the reverse relationship holds for substrates with hydrophilic amino acid residues in the $P_{1}$ position. 
Table II.

The effect of the alcohol leaving group on the kinetic parameters for the CPD-Y, I-Hg-CPD-Y and Ph-Hg-CPD-Y catalyzed hydrolysis of ester substrates.

\begin{tabular}{llcccc}
\hline Enzyme & Substrate & $\begin{array}{c}\text { Substrate range } \\
(\mathrm{mM})\end{array}$ & $\begin{array}{c}\mathrm{k}_{\mathrm{cat}} \\
\left(\mathrm{min}^{-1}\right)\end{array}$ & $\begin{array}{c}\mathrm{K}_{\mathrm{m}} \\
(\mathrm{mM})\end{array}$ & $\begin{array}{c}\mathrm{k}_{\mathrm{cat}} / \mathrm{K}_{\mathrm{m}} \\
\left(\mathrm{min}^{-1}-\mathrm{mM}^{-1}\right)\end{array}$ \\
\hline CPD-Y & Bz-Ala-OMe & $1-25$ & 3100 & 6.3 & 490 \\
& Bz-Ala-OBzl & $0.025-0.5$ & 7400 & 0.07 & 110000 \\
Ph-Hg-CPD-Y & Bz-Ala-OMe & $10-50$ & 940 & 50 & 19 \\
& Bz-Ala-OBzl & $0.1-0.8$ & 3400 & 0.54 & 6300 \\
I-Hg-CPD-Y & Bz-Ala-OMe & $10-50$ & 1100 & 70 & 16 \\
& Bz-Ala-OBzl & $0.1-0.8$ & 3300 & 0.48 & 6900 \\
\hline
\end{tabular}

For Bz-Ala-OMe the rate of hydrolysis was determined by the $\mathrm{pH}$ stat method in $0.1 \mathrm{M}-\mathrm{KCl}$ for CPD-Y and $\mathrm{Ph}-\mathrm{Hg}$ CPD-Y and in 10-4 $\mathrm{M}-\mathrm{KI}$ (saturating concentration) for I-Hg-CPD-Y: The rate of hydrolysis of Bz-Ala-OBzl was determined spectrophotometrically in $0.05 \mathrm{M}-\mathrm{Hepes}, \mathrm{pH} 7.5$, containing $10^{-4} \mathrm{M}-\mathrm{KI}$ for I-Hg-CPD-Y. All assays with the unmodified enzyme contained $1 \mathrm{mM}$-EDTA. All assays with both substrates contained $2.5 \% \mathrm{DMF}$.

$\mathrm{Bz}-\mathrm{Val}-\mathrm{OMe}$ and $\mathrm{Bz}-\mathrm{Ile}-\mathrm{OMe}$ are exceptions from this trend since their hydrolysis is characterized by relatively low $k_{\text {cat }}$ values although both Val and Ile are hydrophobic amino acid residues. Using I-Hg-CPD-Y, a similar pattern is observed. However, $k_{c a:}$ values are generally lower and $\mathrm{K}_{\mathrm{m}}$ values higher than for CPD-Y. One notable exception is the hydrolysis of Bz-Lys-OMe where $k_{\text {cat }}$ for I-Hg-CPD-Y is approximately 40 times higher than for CPD-Y. Using Ph-Hg-CPD-Y, a reduction in $\mathrm{k}_{\mathrm{cat}}$ and an increase in $\mathrm{K}_{\mathrm{m}}$ relative to CPD-Y is observed for all substrates but characteristically the change in $\mathrm{k}_{\mathrm{cat}} / \mathrm{K}_{\mathrm{m}}$ is more pronounced for substrates with bulky side chains than for substrates with none or small side chain, e.g. $k_{\text {cat }} / K_{m}$ for the Ph-Hg-CPD-Y catalyzed hydrolysis of Bz-Gly-OMe is $14 \%$ of $\mathrm{k}_{\mathrm{cat}} / \mathrm{K}_{\mathrm{m}}$ for the CPD-Y catalyzed hydrolysis of Bz-Gly-OMe whereas the corresponding number for Bz-Phe-OMe is $0.7 \%$. For Bz-Gly-OMe and Bz-Ala-OMe the kinetic parameters obtained with $\mathrm{Ph}-\mathrm{Hg}-\mathrm{CPD}-\mathrm{Y}$ are almost identical to those obtained with $\mathrm{l}-\mathrm{Hg}-\mathrm{CPD}-\mathrm{Y}$ while for the rest of the substrates, which are all characterized by large side groups, $k_{\text {cat }}$ is lower and $K_{m}$ is higher for $\mathrm{Ph}-\mathrm{Hg}-\mathrm{CPD}-\mathrm{Y}$ than for I-Hg-CPD-Y.

Since other halides than $\mathrm{I}^{-}$can activate $+\mathrm{Hg}-\mathrm{CPD}-\mathrm{Y}$ the effect of $\mathrm{Cl}-$ and $\mathrm{Br}$ - on the kinetic parameters for ester hydrolysis was also investigated. The results in Table IV demonstrate that $\mathbf{k}_{\text {cat }}$ for the hydrolysis of Bz-Lys-OMe increases in the sequence I-Hg-CPD-Y,
$\mathrm{Br}-\mathrm{Hg}-\mathrm{CPD}-\mathrm{Y}$ and $\mathrm{Cl}-\mathrm{Hg}-\mathrm{CPD}-\mathrm{Y}$ with $\mathrm{k}_{\text {cat }}$ for $\mathrm{Cl}-\mathrm{Hg}-\mathrm{CPD}-\mathrm{Y}$ being 110 fold higher than for CPD-Y. $\mathrm{K}_{\mathrm{m}}$ on the other hand is identical for all three derivatives, and thus independent of the anion used to activate $+\mathrm{Hg}$-CPD-Y. The hydrolysis of $\mathrm{Bz}-\mathrm{Phe}-\mathrm{OMe}$ by $\mathrm{A}-\mathrm{Hg}-\mathrm{CPD}-\mathrm{Y}$ is comparatively unaffected by the nature of the anion used.

The effects of different anions on the A-Hg-CPD-Y catalyzed hydrolysis of analogous peptide substrates with Lys and Phe in the $P_{1}$ position, respectively, were similar to the effects observed for ester substrates. Bx-Lys-Ala-OH was hydrolyzed several times faster and Z-Phe-Ala-OH several times slower by A-Hg-CPD-Y than by unmodified CPD-Y (Table V). Thus, modification of CPD-Y with mercuric chloride also influences the specificity of peptide hydrolysis.

\section{DISCUSSION}

The specificity of proteolytic enzymes has been demonstrated to be dependent on the interaction between enzyme and peptide at multiple sites (for a review, see ref. 9) but only few studies have focused on how these interactions could be perturbed by chemical modification of the enzymes. Such enzyme derivatives would be highly desirable, not only to evaluate the importance of the interactions at a given subsite, but also to modify the specificity of a given proteolytic enzyme. Availability of enzyme derivatives with al- 
Table III.

Kinetic parameters for the hydrolysis of ester substrates with CPD-Y, I-Hg-CPD-Y and Ph-Hg-CPD-Y.

\begin{tabular}{|c|c|c|c|c|c|}
\hline Substrate & Enzyme & $\begin{array}{c}\text { Substrate range } \\
(\mathrm{mM})\end{array}$ & $\begin{array}{c}\mathbf{k}_{\text {cat }} \\
\left(\mathrm{min}^{-1}\right)\end{array}$ & $\begin{array}{c}K_{m} \\
(\mathrm{mM})\end{array}$ & $\begin{array}{c}\mathbf{k}_{\mathrm{ca}} / \mathbf{K}_{\mathrm{m}} \\
\left(\mathrm{min}^{-1} \cdot \mathrm{mM}^{-1}\right) \\
\end{array}$ \\
\hline \multirow{3}{*}{ Bz-Gly-OMe } & CPD-Y & $10 \cdot 75$ & 150 & 48 & 3.1 \\
\hline & I-Hg-CPD-Y & $10-75$ & 20 & 110 & 0.18 \\
\hline & Ph-Hg-CPD-Y & $10-75$ & 40 & 90 & 0.44 \\
\hline \multirow{3}{*}{ Bz-Ala-OMe } & CPD-Y & $1-25$ & 3100 & 6.3 & 490 \\
\hline & I-Hg-CPD-Y & $10-50$ & 1100 & 70 & 16 \\
\hline & $\mathrm{Ph}-\mathrm{Hg}-\mathrm{CPD}-\mathrm{Y}$ & $10-50$ & 940 & 50 & 19 \\
\hline \multirow{3}{*}{ Bz-Val-OMe } & CPD-Y & $0.25-1.5$ & 270 & 1.5 & 180 \\
\hline & I-Hg-CPD-Y & $0.8-4$ & 90 & 4.5 & 20 \\
\hline & Ph-Hg-CPD-Y & $1-4$ & 5 & 2.8 & 1.8 \\
\hline \multirow{3}{*}{ Bz-Ile-OMe } & CPD-Y & $0.25-1$ & 200 & 0.77 & 260 \\
\hline & I-Hg-CPD-Y & $0.25-1$ & 140 & 2.2 & 64 \\
\hline & Ph-Hg-CPD-Y & $0.4-1.25$ & 8 & 10 & 0.8 \\
\hline \multirow{3}{*}{ Bz-Leu-OMe } & CPD-Y & $0.15-1.25$ & 4000 & 0.71 & 5600 \\
\hline & I-Hg-CPD-Y & $0.3-1.0$ & 1000 & 3.3 & 300 \\
\hline & Ph-Hg-CPD-Y & $0.5-2.5$ & 700 & 25 & 30 \\
\hline \multirow{3}{*}{ Bz-Met-OMe } & CPD-Y & $0.25-1.25$ & 2500 & 0.90 & 2800 \\
\hline & I-Hg-CPD-Y & $0.25-1.25$ & 850 & 0.80 & 1100 \\
\hline & Ph-Hg-CPD-Y & $0.25-1.25$ & 66 & 5.0 & 13 \\
\hline \multirow{3}{*}{ Bz-Phe-OMe } & CPD-Y & $0.075-1$ & 9100 & 0.18 & 51000 \\
\hline & I-Hg-CPD-Y & $0.2-1.25$ & 3700 & 1.2 & 3100 \\
\hline & Ph-Hg-CPD-Y & $0.2-1.5$ & 490 & 1.4 & 350 \\
\hline \multirow{3}{*}{ Bz-Lys-OMe } & CPD-Y & $5-50$ & 10 & 18 & 0.56 \\
\hline & I-Hg-CPD-Y & $6-50$ & 410 & 50 & 8.2 \\
\hline & $\mathrm{Ph}-\mathrm{Hg}-\mathrm{CPD}-\mathrm{Y}$ & 10 & 0 & 0 & 0 \\
\hline \multirow{3}{*}{ Bz-Arg-OMe } & CPD-Y & $1.5-100$ & 46 & 3.7 & 12 \\
\hline & I-Hg-CPD-Y & $2.5-25$ & 26 & 4.8 & 5.4 \\
\hline & $\mathrm{Ph}-\mathrm{Hg}-\mathrm{CPD}-\mathrm{Y}$ & 10 & 0 & 0 & 0 \\
\hline \multirow{3}{*}{ Bz-His-OMe } & CPD-Y & $2.5-25$ & 110 & 8.3 & 13 \\
\hline & I-Hg-CPD-Y & $2.5-20$ & 20 & 5.3 & 3.8 \\
\hline & Ph-Hg-CPD-Y & 25 & 0 & 0 & 0 \\
\hline \multirow{3}{*}{ Bz-Thr-OMe } & CPD-Y & $2.5-60$ & 130 & 7.4 & 18 \\
\hline & I-Hg-CPD-Y & $7-60$ & 120 & 50 & 2.4 \\
\hline & $\mathrm{Ph}-\mathrm{Hg}-\mathrm{CPD}-\mathrm{Y}$ & $10-60$ & 10 & 80 & 0.13 \\
\hline
\end{tabular}

The rate of hydrolysis was determined by the $\mathrm{pH}$ stat method for those substrates where concentrations of more than $1.5 \mathrm{~mm}$ was tested. In other cases, the spectrophotometric assay was used. All reactions were performed at $\mathrm{pH}$ 7.5 and the reaction medium contained 2.5\% DMF except for Bz-Lys-OMe, Bz-Arg-OMe and Bz-His-OMe. The spectrophotometric assay was performed in $0.05 \mathrm{M}$-Hepes, containing $1 \mathrm{mM}$-EDTA for CPD-Y and $10^{-4} \mathrm{M}-\mathrm{KI}$ for I$\mathrm{Hg}-\mathrm{CPD}-\mathrm{Y}$. The $\mathrm{pH}$ stat assay was performed in $0.1 \mathrm{M}-\mathrm{KCl}$ for CPD-Y and Ph-Hg-CPD-Y and in $10^{-4} \mathrm{M}-\mathrm{KI}$ (saturating concentration) for I-Hg-CPD-Y. The assay with CPD-Y contained 1 mM-EDTA. 0 means activity was too low to determine the kinetic parameters.

tered specificities (relative to that exhibited by the unmodified enzyme) might be valuable both in protein sequence determinations and in en- zymatic peptide synthesis. Previously, chemical modifications have been demonstrated to influence the interaction between enzyme and sub- 
K. BREDDAM: Modification of carboxypeptidase $\mathrm{Y}$ by mercurials

Table IV.

The influence of different anions on the kinetic parameters of $+\mathrm{Hg}$-CPD-Y catalyzed ester hydrolysis.

\begin{tabular}{llrccc}
\hline Substrate & & CPD-Y & Cl-Hg-CPD-Y & Br-Hg-CPD-Y & I-Hg-CPD-Y \\
\hline \multirow{3}{*}{ Bz-Lys-OMe } & $\mathrm{k}_{\text {cat }}$ & 10 & 1100 & 970 & 410 \\
& $\mathrm{~K}_{\mathrm{m}}$ & 18 & 50 & 50 & 50 \\
& $\mathrm{k}_{\text {cal }} / \mathrm{K}_{\mathrm{m}}$ & 0.56 & 22 & 19 & 8.2 \\
Bz-Phe-OMe & $\mathrm{k}_{\text {cat }}$ & 9100 & 3600 & 4900 & 3700 \\
& $\mathrm{~K}_{\mathrm{m}}$ & 0.18 & 1.2 & 1.3 & 1.2 \\
& $\mathrm{k}_{\text {cat }} / \mathrm{K}_{\mathrm{m}}$ & 51000 & 3000 & 3700 & 3100 \\
\hline
\end{tabular}

The rate of hydrolysis of $\mathrm{Bz}-\mathrm{Lys}-\mathrm{OMe}$ was determined titrimetrically in $0.1 \mathrm{M}-\mathrm{KCl}$ at $\mathrm{pH} 7.5$, whereas for $\mathrm{Bz}-\mathrm{Phe}$ OMe it was determined spectrophotometrically in $0.05 \mathrm{M}$-Hepes, $\mathrm{pH}$ 7.5. Assays with CPD-Y contained $1 \mathrm{~mm}$ EDTA. The mercuric chloride modified enzyme was assayed in the presence of $1 \mathrm{M}-\mathrm{KCl}$ (Cl-Hg-CPD-Y) 20 $\mathrm{mM}-\mathrm{KBr}$ (Br-Hg-CPD-Y) or 10-4 M-KI (I-Hg-CPD-Y). These concentrations of halides result in saturation of $+\mathrm{Hg}$-CPD-Y (see Figure 3). Precautions were taken to ensure that no other halides than those mentioned were present in the assay mixtures.

Table V.

CPD-Y catalyzed peptide hydrolysis.

\begin{tabular}{lcccc}
\hline Substrate & CPD-Y & $\begin{array}{c}\text { Cl-Hg-CPD-Y } \\
\mu \text { moles-min-1 mg-1 }\end{array}$ & $\begin{array}{c}\text { Br-Hg-CPD-Y } \\
\text { I-Hg-CPD-Y }\end{array}$ \\
\hline Z-Phe-Ala-OH & 134 & 17 & 17 & 16 \\
Bz-Lys-Ala-OH & 0.006 & 0.045 & 0.043 & 0.019 \\
\hline
\end{tabular}

The peptidase activity was determined spectrophotometrically at $230 \mathrm{~nm}$ for Z-Phe-Ala-OH and $254 \mathrm{~nm}$ for Bz-Lys-Ala-OH at pH 6.5 using a $0.05 \mathrm{M}-\mathrm{Mes}$ buffer. The enzyme modified with $\mathrm{HgCl}_{2}$ was assayed in the absence of EDTA but in the presence of $1 \mathrm{M}-\mathrm{KCl}, 20 \mathrm{mM}-\mathrm{KBr}$ or $10^{-4} \mathrm{M}-\mathrm{KI}$ (saturating concentrations of anions). The unmodified enzyme was assayed in the presence of $1 \mathrm{mM}$-EDTA.

strate in the neutral metallo-proteases (7), e.g., thermolysin, and in the subtilisins (9). The present study which investigates changes in specificity following modification of CPD-Y with mercuric chloride and phenylmercuric chloride is a continuation of the work by BAI and HAYASHI who produced various derivatives of CPD-Y by reacting the free sulfhydryl group in the $S_{1}$ site with mercurials (1).

As previously demonstrated (1), the reactions with the mercurials were stoichiometric suggesting that the complexes had very low dissociation constants. However, contrary to previous work the present study demonstrates the importance of anions when modification with mercuric ions is performed. Apparent discrepancies in the results were therefore only due to the experimental conditions employed. Thus, BAI and HaYASHI reported (1) that CPD-Y retained $30 \%$ of its activity towards Bz-Gly-L, $\beta$-phenyllactate after modification with mercuric ions because they, unknowingly of the effect of $\mathrm{Cl}^{-}$, measured hydro- lysis rates in $0.1 \mathrm{M}-\mathrm{KCl}$. This result could be confirmed in the present study provided the assay was performed in the presence of $\mathrm{KCl}$. However, when assayed in the absence of $\mathrm{KCl}$ the enzyme retained less than $1 \%$ of its activity towards $\mathrm{Bz}$-Gly-L, $\beta$-phenyllactate and all other substrates investigated in the present study. This lack of activity is possibly due to the mercuric ion forming a bridge between the sulphydryl group in the $\mathrm{S}_{1}$ site and some other amino acid side chain capable of complexing with mercuric ions, e.g. His, Asp, Glu (10). This side chain may be essential for catalysis but the explanation may also be a conformational change which renders the enzyme inactive. The ability of one equivalent of halide $\left(\mathrm{Cl}^{-}, \mathrm{Br}^{-}, \mathrm{I}^{-}, \mathrm{SCN}^{-}\right.$and $\left.\mathrm{CN}^{-}\right)$to reactivate $+\mathrm{Hg}-\mathrm{CPD}-\mathrm{Y}$ is therefore presumably due to its complexation with the mercuric ion thereby breaking the bridge and allowing the enzyme to enter an active conformation again. The complexation of halide ligands to enzyme bound mercury can thus be monitored by recording the 
changes in the activity of the enzyme. ${ }^{+} \mathrm{Hg}-\mathrm{CPD}-\mathrm{Y}$ differs from mercuric ion in solution both with respect to the dissociation constant and the number of ligands (10). Thus, while the free mercuric ion can bind up to four halides ${ }^{+} \mathrm{Hg}-\mathrm{CPD}-\mathrm{Y}$ apparently can bind only one.

The modification of the sulfhydryl group in CPD-Y with $\mathrm{Ph}-\mathrm{Hg}-\mathrm{Cl}$ and $\mathrm{HgCl}_{2}$ is accompanied by a decrease in $\mathrm{k}_{\mathrm{cat}}$ for the hydrolysis of the ester substrates Bz-Ala-OMe and Bz-AlaOBzl (Table II). CPD-Y utilizes an acyl mechanism (4), and a decrease in $\mathrm{k}_{\mathrm{cat}}$ would imply curtainment of the rate-limiting step(s). The present studies show that the alcohol leaving group exerts a pronounced influence on $k_{\text {cal }}$ both for CPD-Y and its two derivatives, a feature which would suggest that the deacylation is not the ratelimiting step for any of the three forms of the enzyme.

The dependence of the $\mathrm{k}_{\mathrm{cal}}$ value for the hydrolysis of Bz-Ala-OBzl on the deprotonation of a group on the enzyme with a $\mathrm{pK}_{\mathrm{a}}$ of approximately 5.2 in the case of unmodified as well as modified CPD-Y's suggest that the free sulfhydryl group is unlikely to be involved in the catalytic mechanism of the enzyme.

The primary objective of this study was to determine whether the modification of CPD-Y with mercurials influenced the specificity of the enzyme. The specificity constant, $k_{c a t} / K_{m}$ was

Table VI.

Specificity of CPD-Y, I-Hg-CPD-Y and Ph-Hg-CPD-Y with respect to the $P_{1}$ position of ester substrates.

\begin{tabular}{lrrr}
\hline Substrate & CPD-Y & I-Hg-CPD-Y & Ph-Hg-CPD-Y \\
\hline Bz-Gly-OMe & 1 & 1 & 1 \\
Bz-Ala-OMe & 160 & 89 & 43 \\
Bz-Val-OMe & 58 & 111 & 4 \\
Bz-Ile-OMe & 84 & 360 & 2 \\
Bz-Leu-OMe & 1800 & 1700 & 68 \\
Bz-Met-OMe & 900 & 6100 & 30 \\
Bz-Phe-OMe & 16000 & 17000 & 790 \\
Bz-Lys-OMe & 0.18 & 46 & 0 \\
Bz-Arg-OMe & 3.9 & 30 & 0 \\
Bz-His-OMe & 4.2 & 21 & 0 \\
Bz-Thr-OMe & 5.8 & 13 & 0.30 \\
\hline
\end{tabular}

The numbers represent relative $k_{c a d} / K_{m}$ values, recalculated from Table III. The values can only be compared within the same column. determined for a variety of $\mathrm{N}$-blocked amino acid ester substrates using unmodified as well as mercurial modified enzymes (Table III). Recalculating these results such that Bz-Gly-OMe (where glycine occupies the $S_{1}$ site) serves as a reference, the comparative assessment of changes in specificity accompanying the modification are listed in Table VI. It is seen that unmodified CPD-Y exhibits a preference for ester substrates with hydrophobic amino acids in the $\mathbf{P}_{1}$ position while substrates with polar side groups in the $P_{1}$ position are generally poor substrates of CPD-Y suggesting that hydrophobic interaction contributes to the binding of substrates to the $S_{1}$ binding site. This is in agreement with results previously reported for peptide substrates (5). The substrates Bz-Val-OMe and $\mathrm{Bz}-\mathrm{Ile}$-OMe, both characterized by a branched $\beta$ carbon at the $P_{I}$ position, form an exception since their hydrolysis are characterized by relatively low $\mathrm{k}_{\text {cat }}$ values. The $\mathrm{k}_{\text {cat }}$ for the hydrolysis of Bz-Leu-OMe is 17 times higher than for Bz-Ile-OMe while the $K_{m}$ values are roughly equal in magnitude. These observations could suggest that the main effect of the branched $\beta$ carbon is to impede the rate limiting step which presumably is the acylation of the enzyme.

The relative $k_{\text {cal }} / K_{m}$ values (Table VI) for the hydrolysis of ester substrates by I-Hg-CPD-Y and Ph-Hg-CPD-Y demonstrate that both enzymes have a specificity which is altered relative to unmodified CPD-Y. Like the native enzyme both derivatives of CPD-Y exhibit a preference for ester substrates with hydrophobic amino acids in the $\mathrm{P}_{1}$ position, i.e., Bz-Leu-OMe, $\mathrm{Bz}-\mathrm{Met}-\mathrm{OMe}$ and Bz-Phe-OMe. However, when comparing the relative values of $k_{c a t} / K_{m}$ for the whole series of $\mathrm{Bz}-\mathrm{X}$-OMe substrates it is evident that a specificity change has occurred as a consequence of the modifications. Relative to native CPD-Y, I-Hg-CPD-Y exhibits an increased preference for the substrates with Val, Ile, Met, Lys, Arg, His and Thr in the $P$, position. The enhanced preference of I-Hg-CPD-Y towards Bz-Lys-OMe is illustrated by the observation that the specificity constant for this substrate is nearly 50 times that observed for Bz-Gly-OMe while in the case of unmodified CPD-Y the latter is the best substrate. With $\mathrm{Ph}-\mathrm{Hg}$-CPD-Y, the relative $\mathrm{k}_{\mathrm{ca}} / \mathrm{K}_{\mathrm{m}}$ is reduced dramatically for all substrates 
except Bz-Ala-OMe which is relatively less affected by the incorporation of the $\mathrm{Ph}-\mathrm{Hg}$-group in the $S_{1}$ site. This is equivalent to an increased preference, relative to unmodified CPD-Y, for Gly and Ala in the $P_{1}$ position. This aspect is well exemplified by a comparison of the $\mathrm{k}_{\text {cal }} / \mathrm{K}_{\mathrm{m}}$ valuesobserved with Bz-Ala-OMeandBz-Met-OMe. With CPD-Y, the preference for Met in the $P_{1}$ position is evident by the 6 fold higher $\mathrm{k}_{\mathrm{ca}} / \mathrm{K}_{\mathrm{m}}$ with Bz-Met-OMe relative to that noted with Bz-Ala-OMe. In contrast, with Ph-Hg-CPD-Y, Bz-Ala-OMe appears to be a better substrate since the observed $\mathrm{k}_{\mathrm{cat}} / \mathrm{K}_{\mathrm{m}}$ value is nearly 1.5 times higher than that recorded with Bz-Met-OMe.

An explanation for the alterations in the specificity of CPD-Y by modification with $\mathrm{Ph}-\mathrm{Hg}$-CPD-Y may be found in the steric hindrance introduced in the $S_{1}$ binding site by the $\mathrm{Ph}-\mathrm{Hg}$-group. The hydrolysis of $\mathrm{Bz}-\mathrm{Phe}-\mathrm{OMe}$ which is characterized by a bulky side chain in the $P_{1}$ position would be expected to be more affected by this modification than the hydrolysis of Bz-Gly-OMe. Since Ph-Hg-CPD-Y exhibits specificity constants different from those exhibited by I-Hg-CPD-Y, the properties of their $S_{1}$ sites presumably vary considerably. Relative to $\mathrm{Ph}-\mathrm{Hg}$-CPD-Y and unmodified CPD-Y, the $\mathrm{S}_{1}$ site of I-Hg-CPD-Y appears more favorable for polar amino acid residues, possibly due to polarization of the $\mathrm{Hg}$-I bond. This hypothesis is consistent with the influence of the anion $\left(\mathrm{Cl}^{-}, \mathrm{Br}, \mathrm{I}^{-}\right)$ on the rate of hydrolysis of Bz-Lys-OMe since the polarization of the $\mathrm{Hg}-\mathrm{A}$ bond will depend on the electronegativity of $A$. Thus, the $S_{1}$ site in $\mathrm{Cl}-\mathrm{Hg}-\mathrm{CPD}-\mathrm{Y}$ possibly is more polar than in I-Hg-CPD-Y and therefore better suited to accommodate a polar amino acid residue. An alternative explanation is based on the ability of such anions, dependent on their electronegativity, to bind water rendering the $S_{1}$ site more hydrophilic. The fact that the hydrolysis of Bz-Lys-Ala-OH is affected by the modification with mercuric chloride in a similar manner as the hydrolysis of $\mathrm{Bz}$-Lys-OMe suggests that the side chain of the lysyl residue in both substrates interact identically with the enzyme and with very little dependence on the nature of the leaving group. This further suggests that the specificity changes observed with respect to the $P_{1}$ position of ester substrates probably also are valid for the $P_{1}$ position of peptide substrates.

The specificity of proteolytic enzymes is determined by the properties of the binding sites. The number of binding sites and the potential binding strength of each of them varies from enzyme to enzyme. For CPD-Y (5), hydrophobic interactions between substrate and enzyme dominate like in other proteolytic enzymes characterized by a wide specificity, e.g., subtilisin and chymotrypsin. This is in contrast to enzymes with a narrow specificity like trypsin where elecrostatic interactions are important (reviewed in ref. 2). The present work demonstrates how specific chemical modifications in one of the primary binding sites can influence substrate-enzyme interactions. By such methods the specificity of proteolytic enzymes can be perturbed and become better adapted to specific purposes.

\section{ACKNOWLEDGEMENTS}

I am indebted to Professor Martin OTtesen for advise during the work and for critically revising the manuscript. Dr. JACK T. JoHANSEN, Dr. Torben Pedersen, Dr. T. Viswanatha and Dr. FRED WIDMER are acknowledged for stimulating discussions. Finally, I am grateful for the outstanding technical assistance of Ms. IRENE SIMONSEN.

\section{REFERENCES}

1. BaI, Y. \& R. HaYashI: Properties of the single sulfhydryl group of carboxypeptidase Y. Effects of alkyl and aromatic mercurials on activities toward various synthetic substrates. J. Biol. Chem. 254, 8473-8479 (1979)

2. BLow, D.M.: Structure and mechanism of chymotrypsin. Accounts. Chem. Res. 9, 145152 (1976)

3. BREDDAM, K., F. WidMer \& J.T. JohanSEN: Influence of the substrate structure on carboxypeptidase $\mathrm{Y}$ catalyzed peptide bond formation. Carlsberg Res. Commun. 45, 361-367 (1980)

4. Douglas, K.T., Y. NaKagawa \& E.T. Kaiser: Mechanistic studies of carboxypeptidase $\mathrm{Y}$. Kinetic detection of an acyl-enzyme intermediate in trimethylacetate esterase action. J. Am. Chem. Soc. 98, 8231-8236 (1976)

5. Hayashi, R., Y. Bai \& T. Hata: Kinetic studies of CPD-Y. I. Kinetic parameters for the hydro- 
lysis of synthetic substrates. J. Biochem. (Tokyo) 77, 69-79 (1975)

6. Johansen, J.T., K. Breddam \& M. Ottesen: Isolation of carboxypeptidase $\mathrm{Y}$ by affinity chromatography. Carlsberg Res. Commun. 41, 1-14 (1976)

7. Holmquist, B., S. Blumberg \& B.L. Vallee: Superactivation of neutral proteases: Acylation with N-hydroxysuccinimide esters. Biochemistry 15, 4675-4680 (1976)
8. SCheChter, J., \& B. Berger: On the size of the active site of proteases: I. Papain. Biochem. Biophys. Res. Commun. 27, 157-162 (1972)

9. Svendsen, I.: Chemical modification of the subtilisins with special reference to the binding of large substrates. A review. Carlsberg Res. Commun. 41, 237-291 (1976)

10. WEBB, J.L.: Enzyme and metabolic inhibitors. Vol III, p. 729, Academic Press (1963) 